\title{
Studies on Peptides. LXX.1,2) Synthesis of Two Octadecapeptides corresponding to the Entire Amino Acid Sequence of Camel $\beta$-Melanocyte-stimulating Hormones
}

\author{
Fusako Tamura, Hiroshi Ogawa, Nobutaka Fujil, Haruaki Yajima, ${ }^{3(a)}$ \\ Kenji Miyata, Masuhisa Nakamura, and Akira Tanaka ${ }^{3 b}$ \\ Faculty of Pharmaceutical Sciences, Kyoto University ${ }^{3 a}$ and \\ Shionogi Research Laboratory, Shionogi Co., Ltd. ${ }^{3 b)}$
}

(Received July 14, 1976)

\begin{abstract}
In a conventional manner, two octadecapeptides corresponding to the entire amino acid sequences of camel $\beta_{1}$ and $\beta_{2}$-MSHs were synthesized. Synthetic peptides exhibited the in vitro MSH activities of $5.1 \times 10^{9}$ and $1.1 \times 10^{9} \mathrm{MSH}$ unit/g, respectively.
\end{abstract}

Keywords_camel $\beta_{1}-\mathrm{MSH}$; Camel $\beta_{2}$-MSH; porcine $\beta$-MSH; $\beta, \beta, \beta$-trichloroethyloxycarbonylhydrazine; anisole-2\% ethanedithiol; hydrogen fluoride procedure; $3 \mathrm{~N}$ Tos-OH hydrolysis of peptides; aminopeptidase digestion of Asp-Gly

In $1975, \mathrm{Li}$, et al.4) elucidated the complete amino acid sequences of two species of $\beta$ melanocyte-stimulating hormones $\left(\beta_{1}\right.$ and $\left.\beta_{2}-\mathrm{MSH}\right)$ from camel pituitary glands and they synthesized these melanotropic principles by the solid phase procedures..$^{5)}$ These structures are quite similar to that of porcine $\left.\beta-\mathrm{MSH}^{6}{ }^{6}\right)$ except that Glu residue at position 2 of porcine $\beta$-MSH is replaced by Gly in both camel $\beta$-MSHs (I and II) and in addition, Gln, instead of Glu, is placed at position 8 in camel $\beta_{1}-\mathrm{MSH}(\mathrm{I})$. We have synthesized two camel $\beta$-MSHs in a conventional manner using available peptide fragments for our recent synthesis of porcine $\beta$-MSH. ${ }^{7} \quad$ Both camel $\beta$-MSHs contain the Asp-Gly bond at the $\mathrm{N}$-terminus. It is known that establishment of this particular peptide bond, without accompanying the contaminant formation of the cyclic succinimide derivatives, is extremely difficult to perform in peptide synthesis, ${ }^{8}{ }^{8}$ since this side reaction is catalysed by both acid and base. Therefore purity of the desired peptide depends upon conditions employed to introduce the Asp-Gly residue to the peptide chain and to remove all protecting groups at the final step of the syn-

1) Part LXIX. H. Yajima, H. Ogawa, N. Fujii, and S. Funakoshi, Chem. Pharm. Bull. (Tokyo), 25, 740 (1977).

2) Amino acids, peptides and their derivatives mentioned in this communication are of the L-configuration. Abbreviations used are those recommended by IUPAC-IUB Commission on Biochemical Nomenclature: Biochem., 5, 2485 (1966); ibid., 6, 362 (1967); ibid., 11, 1726 (1972). Z=benzyloxycarbonyl, $Z(\mathrm{OMe})=p$-methoxybenzyloxycarbonyl, Tos $=p$-toluenesulfonyl, Troc $=\beta, \beta, \beta$-trichloroethyloxycarbonyl, $\mathrm{OBzl}=$ benzyl ester, $\mathrm{ONP}=p$-nitrophenyl ester, $\mathrm{DCC}=$ dicyclohexylcarbodimide, HOBT=N-hydroxybenzotriazole, $\mathrm{TFA}=$ trifluoroacetic acid, $\mathrm{THF}=$ tetrahydrofuran, $\mathrm{DMF}=$ dimethylformamide.

3) Location: a) 606, Sakyo-ku, Kyoto; b) 553, Fukushima, Osaka.

4) C.H. Li, W.O. Danho, D. Chung, and A.J. Rao, Biochem., 14, 947 (1975).

5) C.H. Li, D. Yamashiro, and S. Lemaire, Biochem., 14, 953 (1975); S. Lemaire, D. Yamashiro, and C.H. Li, J. Med. Chem., 19, 373 (1976).

6) J.I. Harris and P. Ross, Nature, 179, 90 (1956), idem, Biochem. J., 71, 434 (1959); I.I. Geshwind, C.H. Li, and L. Bernafi, J. Am. Chem. Soc., 78, 4494 (1956); I.I. Geshwind and C.H. Li, ibid., 79, 615 (1957).

7) H. Watanabe, H. Ogawa, and H. Yajima, Chem. Pharm. Bull. (Tokyo), 23, 375 (1975).

8) A.B. Battersby and J.C. Robinson, J. Chem. Soc., 1955, 239; E. Sondheimer and R.W. Holley, J. Am. Chem. Soc., 76, 2467 (1954); S.A. Bernhard, A. Berger, J.H. Carter, E. Katchalski, E. Sela, and Y. Shalitin, ibid., 84, 2421 (1962); G. Folsch, Acta Chem. Scand., 20, 459 (1966); E.E. Haley and B.J. Corcoran, Biochem., 6, 2668 (1967); K. Weber and W. Konigsberg, J. Biol. Chem., 242, 3563 (1967); M. Bodanszky and S. Natarajan, J. Org. Chem., 40, 2495 (1975) and see other references thereon. 
thesis by acid, in our case by hydrogen fluoride.9,10) Ondetti, et al..$^{\mathbf{1 1})}$ synthesized porcine secretin after introduction of the $\mathrm{N}$-terminal tetrapeptide containing Asp-Gly by the azide procedure $^{\mathbf{1 2})}$ and mentioned that by other means, such as carbonyldiimidazole ${ }^{13)}$ or the mixed anhydride, ${ }^{14)}$ complicated mixtures were formed. Referring to these results, we decided to

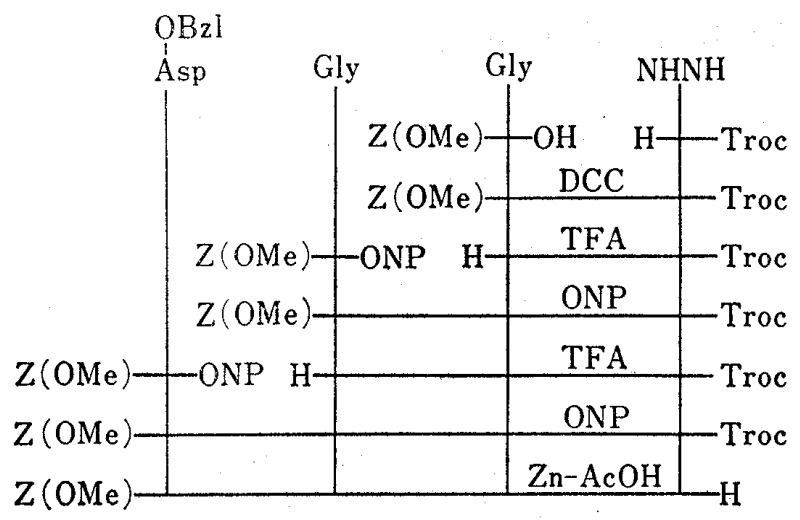

Fig. 1. Synthetic Scheme of the Protected Tripeptide Hydrazide use the $\mathrm{N}$-terminal tripeptide hydrazide as a building block for the synthesis of both camel $\beta$-MSHs.

Synthetic scheme of the $\mathrm{N}$-terminal tripeptide hydrazide, $\mathrm{Z}(\mathrm{OMe})$-Asp(OBzl)Gly-Gly-NHNH${ }_{2}$, is illustrated in Fig. 1. Since the usual hydrazine treatment of Asp $(\mathrm{OBzl})$-peptide esters is not possible, Troc-hydrazine, ${ }^{15}$ ) a substituted hydrazine introduced by us in 1971, served to prepare this hydrazide. Practical application of this substituted hydrazine was previously demonstrated in two synthetic examples: dogfish $\mathrm{MSH}^{16)}$ and gastric inhibiting polypeptide. ${ }^{17)} \mathrm{Z}(\mathrm{OMe})$-Gly-NHNH-Troc was obtained as a crystalline compound by the the DCC procedure. ${ }^{18)}$ This, after deprotection of the $Z(\mathrm{OMe})$ group ${ }^{19)}$ with TFA, was condensed with $Z(\mathrm{OMe})-\mathrm{Gly}-\mathrm{OH}$ by the $p$-nitrophenyl ester procedure ${ }^{20)}$ to give $Z(\mathrm{OMe})$ Gly-Gly-NHNH-Troc, to which $\mathrm{Z}(\mathrm{OMe})-\mathrm{Asp}(\mathrm{OBzl})-\mathrm{OH}$ was introduced by the similar deprotection and the active ester procedure. Especially the latter condensation was accelerated by addition of HOBT. ${ }^{21)}$ The Troc group was then deprotected from the resulting protected tripeptide, $\mathrm{Z}(\mathrm{OMe})-\mathrm{Asp}(\mathrm{OBzl})-\mathrm{Gly}-\mathrm{Gly}-\mathrm{NHNH}-\mathrm{Troc}$, with $\mathrm{Zn}-\mathrm{AcOH}^{22)}$ and

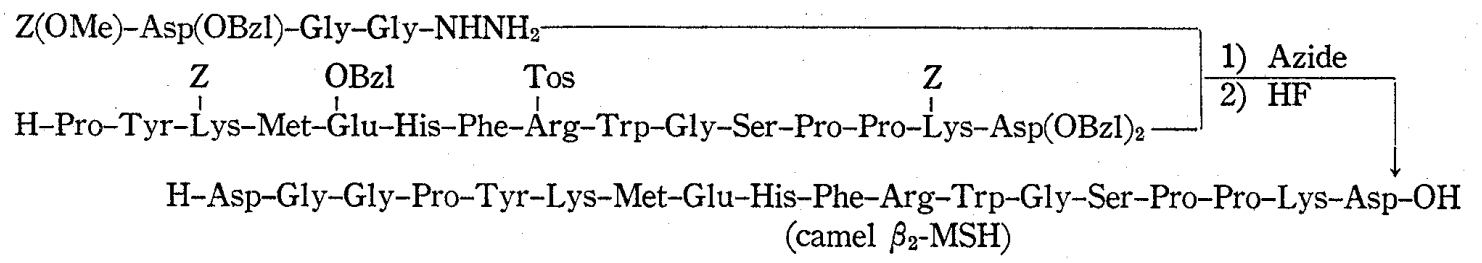

Fig. 2. Synthetic Route to Camel $\beta_{2}-\mathrm{MSH}$ (II)

9) S. Sakakibara, Y. Shimonishi, Y. Kishida, H. Okada, and H. Sugihara, Bull. Chem. Soc. Japan, 40, 2164 (1967).

10) T. Baba, H. Sugiyama, and S. Seto, Chem. Pharm. Bull. (Tokyo), 21, 207 (1973).

11) M.A. Ondetti, V.L. Naraganan, M. von Saltza, J.T. Sheehan, E.F. Sabo, and M. Bodanszky, J. Am. Chem. Soc., 90, 4711 (1968); M.A. Ondetti, A. Deer, J.T. Sheehan, J. Pluscec, and O. Kocy, Biochem., 7, 4069 (1968).

12) T. Curtius, Chem. Ber., 35, 3226 (1902).

13) H.A. Staab, Ann. Chem., 609, 75 (1957); G.W. Anderson and R. Paul, J. Am. Chem. Soc., 80, 4423 (1958); ibid., 82, 4596 (1960).

14) Th. Wieland and H. Bernhard, Ann. Chem., 572, 190 (1951).

15) H. Yajima and Y. Kiso, Chem. Pharm. Bull. (Tokyo), 19, 420 (1971).

16) H. Watanabe, M. Kubota, H. Yajima, A. Tanaka, M. Nakamura, and T. Kawabata, Chem. Pharm. Bull. (Tokyo), 22, 1889 (1974).

17) H. Ogawa, M. Kubota, H. Yajima, T. Tobe, M. Fujimura, K. Henmi, K. Torizuka, T. Adachi, H. Imura, and T. Taminato, Chem. Pharm. Bull. (Tokyo), 24, 2447 (1976).

18) J.C. Sheehan and G.P. Hess, J. Am. Chem. Soc., 77, 1067 (1955).

19) M. Bodanszky, Acta Chem. Hung., 10, 335 (1957).

20) F. Weygand and K. Hunger, Chem. Ber., 95, 1 (1962); H. Yajima, F. Tamura, and Y. Kiso, Chem. Pharm. Bull. (Tokyo), 18, 2574 (1970).

21) W. König and R. Geiger, Chem. Ber., 106, 3626 (1973).

22) R.B. Woodward, K. Heusler, J. Gosteli, P. Naegeli, W. Oppolzer, R. Ramage, S. Ranganahan, and H. Vorbruggen, J. Am. Chem. Soc., 88, 852 (1966). 
contamination of metal was removed by EDTA (ethylenediamine tetraacetic acid disodium salt). Thus $Z(\mathrm{OMe})-\mathrm{Asp}(\mathrm{OBzl})-\mathrm{Gly}-\mathrm{Gly}-\mathrm{NHNH}_{2}$ was obtained in an analytically pure form.

Synthesis of camel $\beta_{2}$-MSH was first carried out as shown in Fig. 2. The modified azide procedure ${ }^{23)}$ was employed to condense the above stated tripeptide hydrazide with the TFA treated pentadecapeptide ester, H-Pro-Tyr-Lys(Z)-Met-Glu(OBzl)-His-Phe-Arg(Tos)-Trp-GlySer-Pro-Pro-Lys $(Z)$-Asp $(\mathrm{OBzl})_{2}$, a synthetic intermediate of porcine $\beta$-MSH. ${ }^{7}$ we wish to mention that in this synthesis, we used anisole containing $2 \%$ ethanedithiol ${ }^{24)}$ as a cation scavenger during the $Z(\mathrm{OMe})$ deprotection with TFA in order to minimize destruction of the Trp residue present in the pentadecapeptide, since it was found that this system is much effective than the anisole-mercaptoethanol system ${ }^{25)}$ employed in the previous synthesis of porcine $\beta$-MSH. Thus we could carried out the TFA treatment without producing any brown color. In order to suppress the possible side reaction of the Asp(OBzl)-Gly residue during the azide condensation reaction, the $\mathrm{pH}$ of the solution was maintained as possible around 7.5. The product was purified by batchwise washing followed by precipitation from THF with ethyl acetate. Purity of the thin layer chromatographically homogeneous sample of protected octadecapeptide ester, Z(OMe)-Asp(OBzl)-Gly-Gly-Pro-TyrLys(Z)-Met-Glu(OBzl)-His-Phe-Arg(Tos)-Trp-Gly-Ser-Pro-Pro-Lys(Z)-Asp(OBzl) $)_{2}$ thus obtained, was further assessed by elemental analysis and by hydrolysis with $6 \mathrm{~N}$ hydrochloric acid and $3 \mathrm{~N} p$-toluenesulfonic acid. ${ }^{26)}$ Especially the content of Arg was determined by the former hydrolysis and Trp in the latter.

The protected octadecapeptide ester was next exposed to hydrogen fluoride ${ }^{9)}$ to remove all protecting groups. The reaction was performed in the presence of anisole, dithiothreitol and skatol ${ }^{27}$ ) in an ice-bath for 60 minutes and the excess hydrogen fluoride was evaporated carefully under cooling with ice in vacuo to suppress possible side reactions, which may occur at $\mathrm{Glu}(\mathrm{OBzl})^{28)}$ and $\mathrm{Asp}(\mathrm{OBzl})$, since it is known that these anticipated side reactions are both temperature dependent. The deblocked peptide, after conversion to the corresponding acetate with Amberlite $C G-4 B$, was purified by column chromatography on Sephadex G-10 and subsequently on CM-cellulose. To elute the desired compound, $3 \%$ acetic acid was used in the former step and gradient elution with $0.1 \mathrm{~m}$ ammonium acetate buffer $(\mathrm{pH}$ $6.9)$ in the latter.

Synthetic camel $\beta_{2}$-MSH thus isolated exhibited a single spot on thin layer chromatography in two different solvent systems and migrated as a single component in the disc electrophoresis at $\mathrm{pH}$ 2.3. On paper electrophoresis in pyridine acetate buffer at $\mathrm{pH} 3.6$, the synthetic peptide gave a single spot with the $R f$ value of 0.48 relative to Lys. This value is in closely agreement with that reported by $\mathrm{Li}$, et al. ${ }^{5)}$ at $\mathrm{pH}$ 3.7. A hydrolysate with $3 \mathrm{~N}$ $p$-toluenesulfonic acid ${ }^{26)}$ contained the constituent amino acids in ratios predicted by theory. Aminopeptidase digestion is expected to give us information about a possible content of the succinimide or $\beta$-Asp type of analogues in our synthetic peptide. Since the Asp-Gly bond locates at the N-terminal portion of $\beta_{2}-\mathrm{MSH}$, recovery of constituent amino acids in a hydrolysate should be decreased depending, if any, on the amount of peptides containing such unnatural peptide bonds. Beacham, et al. ${ }^{29)}$ mentioned that rate of hydrolysis of the Asp-

23) J. Honzl and J. Ruginder, Coll. Czech. Chem. Commun., 26, 2333 (1961).

24) J.J. Sharp, A.B. Robinson, and M.D. Kamen, J. Am. Chem. Soc., 95, 6097 (1973).

25) G.R. Marshall, Advan. Exp. Med., 2, 48 (1969); H. Yajima, H. Kawatani, and H. Watanabe, Chem. Pharm. Bull. (Tokyo), 10, 1333 (1970).

26) T.Y. Liu and Y.H. Chang, J. Biol. Chem., 246, 2842 (1971).

27) C. Hatanaka, O. Nishimura, and M. Fujino, Chem. Pharm. Bull. (Tokyo), 23, 1017 (1975).

28) S. Sano and S. Kawanishi, J.Am. Chem. Soc., 97, 3480 (1975); R.S. Feinberg and R.B. Merrifield, ibid., 97, 3485 (1975).

29) J. Beacham, G. Dappis, F.M. Finn, H.T. Story, C. Yanaihara, N. Yanaihara, and K. Hofmann, J. Am. Chem. Soc., 93, 5526 (1971). 
Gly bond by $\mathrm{AP}-\mathrm{M}^{30}$ ) is abnormally slow and recovery of $88 \%$ was achieved after 40 $\mathrm{hr}$ 's incubation. When we then examined a $40 \mathrm{hr}$ 's hydrolysate, average recovery of amino acids was $87 \%$. The result indicated that the octadecapeptide we isolated is not contaminated with a sizable amount of peptide containing unnatural peptide bonds.

Synthesis of camel $\beta_{1}$-MSH was next carried out according to the scheme illustrated in Fig. 3. Since this hormone possesses the Gln residue at position $8, Z(O M e)-G \ln -\mathrm{His}-\mathrm{Phe}-$

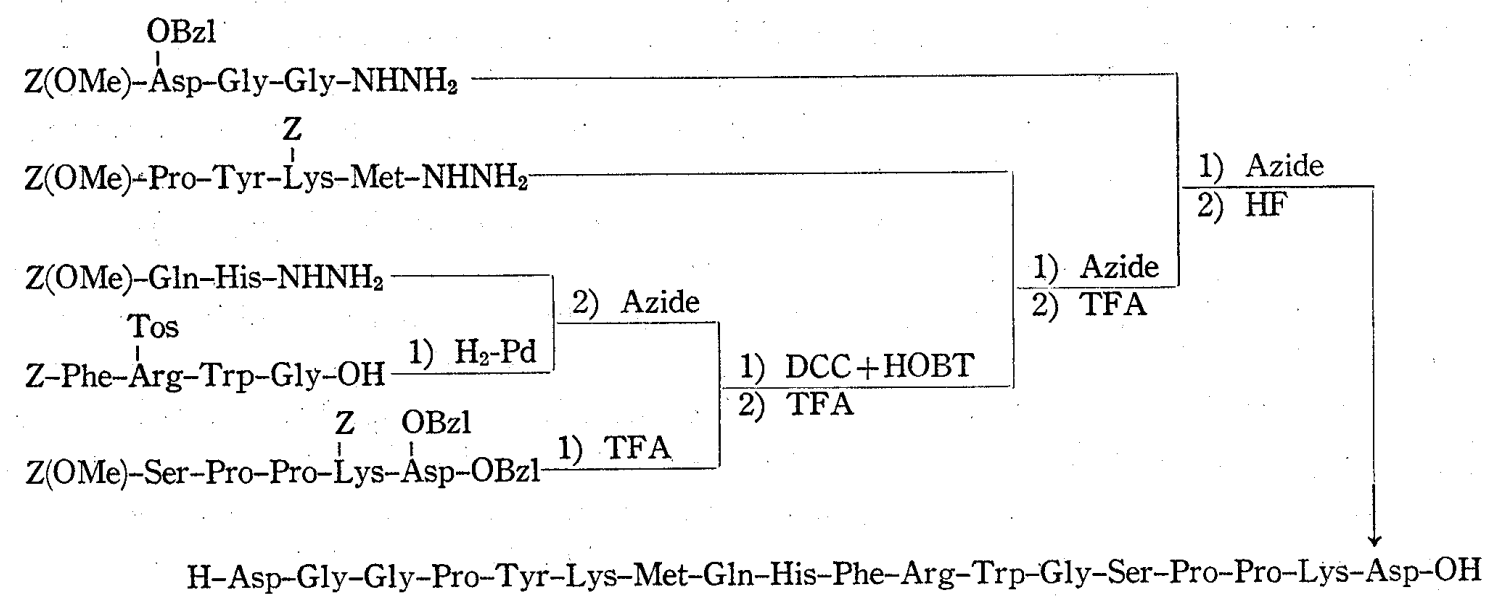

Fig. 3. Synthetic Route to Camel $\beta_{1}-\mathrm{MSH}(\mathrm{I})$

$\operatorname{Arg}(\mathrm{Tos})-\mathrm{Trp}-\mathrm{Gly}-\mathrm{OH}$ was first prepared at a building block. This peptide unit was synthesized previously by Kappeler ${ }^{31)}$ in a form of $Z$-Gln-His-Phe-Arg-Trp-Gly-OMe in connection with the synthesis of ACTH active peptides. In our present synthesis, $Z(\mathrm{OMe})$-Gln-HisOMe prepared by the $p$-nitrophenyl ester procedure, was converted in the usual manner to $\mathrm{Z}(\mathrm{OMe})-\mathrm{Gln}-\mathrm{His}-\mathrm{NHNH}_{2}$, which was further condensed by the azide procedure with H-PheArg(Tos)-Trp-Gly-OH derived from the Z-derivative. ${ }^{7}$ The resulting protected hexapeptide was purified by batchwise washing followed by precipitation from DMF with methanol.

The DCC plus HOBT condensation ${ }^{32)}$ of this hexapeptide with H-Ser-Pro-Pro-Lys $(Z)$ Asp $(\mathrm{OBzl})_{2}{ }^{7)}$ and subsequent azide condensation of $\mathrm{Z}(\mathrm{OMe})$-Pro-Tyr-Lys $(\mathrm{Z})$-Met-NHNH${ }_{2}{ }^{7}$ with the undecapeptide ester obtained in the above reaction were carried out in essentially the same manner as described in the synthesis of porcine $\beta$-MSH ${ }^{7}$ and respective products were purified by column chromatography on silica. Next, the resulting protected pentadecapeptide ester, Z(OMe)-Pro-Tyr-Lys(Z)-Met-Gln-His-Phe-Arg(Tos)-Trp-Gly-Ser-Pro-Pro-Lys(Z)$\mathrm{Asp}(\mathrm{OBzl})_{2}$, was treated with TFA under conditions mentioned above and subsequently condensed with $\mathrm{Z}(\mathrm{OMe})-\mathrm{Asp}(\mathrm{OBzl})$-Gly-Gly- $\mathrm{NHNH}_{2}$ as performed in the synthesis of $\beta_{2}-\mathrm{MSH}$ with controlling the $\mathrm{pH}$ of the solution carefully. The protected octadecapeptide ester, $\mathrm{Z}$ $(\mathrm{OMe}$ - Asp (OBzl) - Gly-Gly-Pro-Tyr-Lys(Z)-Met-Gln-His-Phe-Arg(Tos)-Trp-Gly-Ser-Pro-ProLys $(Z)-A s p(O B z l)_{2}$ thus synthesized, was then exposed to hydrogen fluoride and the deblocked peptide was purified in essentially the same manner utilizing experiences obtained above. Homogeneity of the product was assessed by thin-layer chromatography, disc electrophoresis at $\mathrm{pH} 2.3$ and hydrolysis with $3 \mathrm{~N} p$-toluenesulfonic acid as did in the synthetic $\beta_{2}$-MSH. In addition, one mole of Gln in the molecule was confirmed by AP-M digest, in which average recovery of amino acids was $88 \%$. Synthetic $\beta_{1}$-MSH migrated in a little bit faster rate than $\beta_{2}$-MSH on paper electrophoresis at $\mathrm{pH} 3.6$ pyridine acetate buffer as expected from the report of $\mathrm{Li}$, et al. ${ }^{5}$

30) G. Pfleiderer and G.P. Celliers, Biochem. Z., 339, 186 (1963), K. Hofmann, F.M. Finn, M. Limetti, J. Montbeller, and G. Zanetti, J. Am. Chem. Soc., 88, 3633 (1966).

31) H. Kappeler, Helv. Chim. Acta, 44, 476 (1961).

32) W. König and R. Geiger, Chem. Ber., 103, 788 (1970). 
MSH activity was determined in vitro using the frog skins (Rana pipiens, six points design) according to Nakamura, et al..$\left.^{33}\right)$ When the potency of synthetic a-MSH $\left(2 \times 10^{10}\right.$ MSH U/g) ${ }^{34)}$ was taken as a standard, relative potencies of synthetic camel $\beta_{1}$ and $\beta_{2}$-MSH were $0.256\left(5.13 \times 10^{9} \mathrm{MSH} \mathrm{U} / \mathrm{g}\right)$ and $0.056\left(1.14 \times 10^{9} \mathrm{MSH} \mathrm{U} / \mathrm{g}\right)$ respectively. Thus it can be concluded that $\beta_{1}-\mathrm{MSH}$ is a much stronger melanotropic principle than $\beta_{2}$-MSH by owing to the single amino acid variation at the position 8 (Gln and Glu). "This tendency is well consistent with the report of $\mathrm{Li}$, et al. ${ }^{4)}$ in the natural hormones.

\section{Experimental}

General experimental methods employed here are essentially the same as reported in the Part $62^{35)}$ of this series. $R f$ values refer to the following solvent systems: $R f_{1} \mathrm{CHCl}_{3}-\mathrm{MeOH}-\mathrm{H}_{2} \mathrm{O}(8: 3: 1), R f_{2} n-\mathrm{BuOH}-$ AcOH-pyridine- $\mathrm{H}_{2} \mathrm{O}(4: 1: 1: 2), R f_{3} n$-BuOH-AcOH-pyridine- $\mathrm{H}_{2} \mathrm{O}(30: 6: 20: 24), R f_{4} n$-BuOH-AcOHpyridine- $\mathrm{H}_{2} \mathrm{O}(30: 20: 6: 24)$.

$\mathbf{Z}(\mathbf{O M e})$-Gly-NHNH-Troc-DCC (4.54 g) was added to a mixture of $\mathrm{Z}(\mathrm{OMe})-\mathrm{Gly}-\mathrm{OH}(4.78 \mathrm{~g})$ and Troc- $\mathrm{NHNH}_{2}(4.98 \mathrm{~g})$ in AcOEt $(100 \mathrm{ml})$ and the mixture was stirred at room temperature overnight. The solution was filtered and the filtrate was condensed in vacuo. The residue was triturated with ether and petroleum ether and recrystallized from ether; yield $7.52 \mathrm{~g}(81 \%), \mathrm{mp} 82-83^{\circ}, R f_{1} 0.54$. Anal. Calcd. for $\mathrm{C}_{14} \mathrm{H}_{16} \mathrm{O}_{6} \mathrm{~N}_{3} \mathrm{Cl}_{3}: \mathrm{C}, 39.22 ; \mathrm{H}, 3.76 ; \mathrm{N}, 9.80$. Found: $\mathrm{C}, 39.20 ; \mathrm{H}, 3.87 ; \mathrm{N}, 9.73$.

Z(OMe)-Gly-Gly-NHNH-Troc-Z Z(OMe)-Gly-NHNH-Troc (7.52 g) was treated with TFA ( $8.0 \mathrm{ml})$ in the presence of anisole $(5.0 \mathrm{ml})$ in an ice-bath for $60 \mathrm{~min}$ and the excess TFA was removed by evaporation. The residue was washed with petroleum ether, dried over $\mathrm{KOH}$ pellets in vacuo for $3 \mathrm{hr}$ and then dissolved in THF $(80 \mathrm{ml})$, to which HOBT $(2.16 \mathrm{~g}), \mathrm{Z}(\mathrm{OMe})-\mathrm{Gly}-\mathrm{ONP}(6.45 \mathrm{~g})$ and $\mathrm{Et}_{3} \mathrm{~N}(2.4 \mathrm{ml})$ were combined. The mixture was stirred at room temperature for $24 \mathrm{hr}$, the solvent was evaporated and the residue was dissolved in AcOEt, which was washed with $10 \%$ citric acid and $\mathrm{H}_{2} \mathrm{O}$, dried over $\mathrm{Na}_{2} \mathrm{SO}_{4}$ and then evaporated. The residue was triturated with ether and then recrystallized from THF and ether; yield $5.86 \mathrm{~g}(71 \%)$, mp 99-101 ${ }^{\circ}, R f_{1}$ 0.57. Anal. Calcd. for $\mathrm{C}_{16} \mathrm{H}_{19} \mathrm{O}_{7} \mathrm{~N}_{4} \mathrm{Cl}_{3}: \mathrm{C}, 39.56 ; \mathrm{H}, 3.94 ; \mathrm{N}, 11.54$. Found: $\mathrm{C}, 39.77 ; \mathrm{H}$, $4.18 ; \mathrm{N}, 11.73$.

Z(OMe)-Asp (OBzl)-Gly-Gly-NHNH-Troc-Z Z(OMe)-Gly-Gly-NHNH-Troc (4.86 g) was treated with TFA $(7 \mathrm{ml})$ in the presence of anisole $(5.4 \mathrm{ml})$ in an ice-bath for $60 \mathrm{~min}$ and the excess TFA was evaporated. The residue was washed with petroleum ether, dried over $\mathrm{KOH}$ pellets in vacuo and dissolved in DMF (50 ml), to which $\mathrm{Et}_{3} \mathrm{~N}(1.4 \mathrm{ml})$, HOBT $(1.35 \mathrm{~g})$ and $\mathrm{Z}(\mathrm{OMe})-\mathrm{Asp}(\mathrm{OBzl})-\mathrm{ONP}(6.10 \mathrm{~g})$ were combined. The mixture was stirred at room temperature for $24 \mathrm{hr}$ and the solvent was evaporated in vacuo. The residue was dissolved in $\mathrm{AcOE}$, which was washed with $10 \%$ citric acid and $\mathrm{H}_{2} \mathrm{O}-\mathrm{NaCl}$, dried over $\mathrm{Na}_{2} \mathrm{SO}_{4}$ and then evaporated. Treatment of the residue with ether afforded a powder, which was recrystallized from $\mathrm{MeOH}$ and ether; yield $4.73 \mathrm{~g}(68 \%), \mathrm{mp} 86-87^{\circ},[\alpha]_{\mathrm{D}}^{20}-6.3^{\circ}(c=0.9, \mathrm{DMF}), R f_{1}$ 0.53. Anal. Calcd. for $\mathrm{C}_{27} \mathrm{H}_{30} \mathrm{O}_{10} \mathrm{~N}_{5} \mathrm{Cl}_{3}: \mathrm{C}$, $46.93 ; \mathrm{H}, 4.38 ; \mathrm{N}, 10.14$. Found: $\mathrm{C}, 47.00 ; \mathrm{H}, 4.67 ; \mathrm{N}, 10.02$.

$\mathrm{Z}(\mathrm{OMe})-\mathrm{Asp}(\mathbf{O B z l})-\mathrm{Gly}-\mathrm{Gly}-\mathrm{NHNH}_{2}-Z(\mathrm{OMe})-\mathrm{Asp}(\mathrm{OBzl})-\mathrm{Gly}-\mathrm{Gly}-\mathrm{NHNH}-\mathrm{Troc}(2.76 \mathrm{~g})$ was dissolved in $\mathrm{AcOH}-\mathrm{DMF}(15 \mathrm{ml}-5 \mathrm{ml})$ and $\mathrm{Zn}$ powder $(2 \mathrm{~g})$ was added and the mixture was stirred at room temperature for $1 \mathrm{hr}$. After addition of fresh $\mathrm{Zn}$ powder $(1 \mathrm{~g})$, stirring was continued for an additional $2 \mathrm{hr}$. The $\mathrm{Zn}$ dust was removed by filtration, the filtrate was condensed in vacuo, the residue was treated with a saturated solution of EDTA $(20 \mathrm{ml})$ and the $\mathrm{pH}$ of the solution was adjusted with $\mathrm{NaHCO}_{3}$ to 7 . The resulting gelatinous mass, after storage in a refrigerator overnight, was collected by filtration, washed batchwisely with $\mathrm{H}_{2} \mathrm{O}$, precipitated from DMF with ethanol and recrystallized from hot $\mathrm{MeOH}$; yield $2.06 \mathrm{~g}(60 \%), \mathrm{mp} 154-158^{\circ}$, $[\alpha]_{\mathrm{D}}^{20}-18.9^{\circ}(c=0.9, \mathrm{DMF}), R f_{1}$ 0.57. Anal. Calcd. for $\mathrm{C}_{24} \mathrm{H}_{29} \mathrm{O}_{8} \mathrm{~N}_{5}: \mathrm{C}, 55.91 ; \mathrm{H}, 5.67 ; \mathrm{N}, 13.59$. Found: $\mathrm{C}, 55.77 ; \mathrm{H}, 5.71 ; \mathrm{N}, 13.42$.

Z(OMe)-Asp (OBzl) -Gly-Gly-Pro-Tyr-Lys (Z)-Met-Glu (OBzl) - His - Phe - Arg (Tos) - Trp - Gly - Ser - Pro - Pro $\mathbf{L y s}(\mathbf{Z})-\mathbf{A s p}(\mathbf{O B z l})_{2}$ - The protected pentadecapeptide, Z(OMe)-Pro-Tyr-Lys(Z)-Met-Glu(OBzl)-His-Phe$\operatorname{Arg}(\mathrm{Tos})-\operatorname{Trp}-\mathrm{Gly}-\mathrm{Ser}-$ Pro-Pro-Lys(Z)-Asp $(\mathrm{OBzl})_{2}{ }^{7}{ }^{2}(0.27 \mathrm{~g})$ was treated with TFA $(0.5 \mathrm{ml})$ in the presence of anisole $(0.3 \mathrm{ml})$ containing $2 \%$ ethanedithiol in an ice-bath for $60 \mathrm{~min}$ and dry ether was added. The resulting powder was collected by filtration, dried over $\mathrm{KOH}$ pellets in vacuo and then dissolved in DMF $(2 \mathrm{ml})$ containing $\mathrm{Et}_{3} \mathrm{~N}(0.28 \mathrm{ml})$. $\mathrm{Z}(\mathrm{OMe})-\mathrm{Asp}(\mathrm{OBzl})-\mathrm{Gly}-\mathrm{Gly}-\mathrm{NHNH}_{2}(0.10 \mathrm{~g})$ was dissolved in an ice-cold mixture of DMF $(2 \mathrm{ml})$ and $2.98 \mathrm{~N}$ HCl-DMF $(0.15 \mathrm{ml})$ and isoamylnitrite $(0.03 \mathrm{ml})$ was added." The solution, after stirring for $5 \mathrm{~min}$, was neutralized with $\mathrm{Et}_{3} \mathrm{~N}(0.74 \mathrm{mI})$ and then combined with the above ice-cold solution containing pentadecapeptide ester. The mixture was stirred at $4^{\circ}$ for $48 \mathrm{hr}$, meanwhile the $\mathrm{pH}$ of the solution was examined in several times and maintained about at 7.5 by addition of $\mathrm{Et}_{3} \mathrm{~N}$. The solvent,

33) M. Nakamura, A. Tanaka, M. Hirata, and S. Inouye, Endocrinol Japan, 19, 383 (1972).

34) H. Yajima, K. Kawasaki, Y. Okada, H. Minami, K. Kubo, and I. Yamashita, Chem. Pharm. Bull. (Tokyo), 16, 919 (1968).

35) H. Ogawa, M. Kubota, and H. Yajima, Chem. Pharm. Bull. (Tokyo), 24, 2428 (1976). 
after addition of a few drops of $\mathrm{AcOH}$, was evaporated. Treatment of the residue with $3 \% \mathrm{AcOH}$ afforded a powder, which was washed batchwisely with $3 \% \mathrm{AcOH}$ and $\mathrm{H}_{2} \mathrm{O}$ and then precipitated twice from DMF with ether; yield $0.25 \mathrm{~g}(80 \%), \operatorname{mp} 170-173^{\circ},[\alpha]_{\mathrm{D}}^{20}-34.7^{\circ}(c=0.3, \mathrm{DMF}), R f_{1} 0.56$. Amino acid ratios in $3 \mathrm{~N}$ Tos-OH hydrolysate: Asp 2.15, Gly 3.17, Pro 2.71, Tyr 0.87, Lys 1.89, Met 0.80, Glu 1.09, His 1.00 , Phe $1.00, \operatorname{Trp} 0.94$, Ser 0.93 (average recovery $80 \%$ ). Amino acid ratios in $6 \mathrm{~N} \mathrm{HCl}$ hydrolysate: Asp 2.13, Gly 3.10 , Pro 2.67, Tyr 0.75, Lys 1.90, Met 0.89; Glu 1.10, His 1.03, Phe 1.09, Arg 1.00, Ser 0.83 (average recovery $81 \%$ ). Anal. Calcd. for $\mathrm{C}_{155} \mathrm{H}_{184} \mathrm{O}_{36} \mathrm{~N}_{26} \mathrm{~S}_{2} \cdot 6 \mathrm{H}_{2} \mathrm{O}: \mathrm{C}, 58.92 ; \mathrm{H}, 6.25, \mathrm{~N}, 11.53$. Found: $\mathrm{C}, 58.53 ; \mathrm{H}, 5.91 ; \mathrm{N}, 11.84$.

H-Asp-Gly-Gly-Pro-Tyr-Lys-Met-Glu-His-Phe-Arg-Trp-Gly-Ser-Pro-Pro-Lys-Asp-OH, Camel $\beta_{2}$-MSH (II) -The above protected octadecapeptide ester $(232 \mathrm{mg}$ ) was treated with HF (approximately $5 \mathrm{ml}$ ) in the presence of anisole $(0.5 \mathrm{ml})$, skatole $(50 \mathrm{mg})$ and dithiothreitol $(40 \mathrm{mg})$ in an ice-bath for $60 \mathrm{~min}$. The excess $\mathrm{HF}$ was evaporated at $0^{\circ}$ and AcOEt was added. The resulting powder was collected by filtration and dissolved in $\mathrm{H}_{2} \mathrm{O}(20 \mathrm{ml})$, which was treated with Amberlite $\mathrm{CG}-4 \mathrm{~B}$ (type II, acetate form, ca $3 \mathrm{~g}$ ) for $30 \mathrm{~min}$ and then filtered. The filtrate was lyophilized and the residue $(178 \mathrm{mg})$ was dissolved in a small amount of $3 \% \mathrm{AcOH}$. The solution was applied to a column of Sephadex G-10 $(3.0 \times 140 \mathrm{~cm})$, which was eluted with $3 \% \mathrm{AcOH}$. Individual fractions $(5 \mathrm{ml})$ were collected and absorbancy at $280 \mathrm{~m} \mu$ was determined. Fractions corresponding to the front main peak (tube 77-130) were combined and the solvent was removed by lyophilization to give a fluffy powder; yield $141 \mathrm{mg}$ (deblocking step $88 \%$ ). This product $(100 \mathrm{mg}$ ) was dissolved. in $\mathrm{H}_{2} \mathrm{O}(5 \mathrm{ml})$ and the solution was applied to a column of CM-cellulose $(2.2 \times 4.0 \mathrm{~cm})$, which was eluted first with $\mathrm{H}_{2} \mathrm{O}(120 \mathrm{ml})$ and then by gradient elution with $0.1 \mathrm{~m} \mathrm{AcONH}_{4}$ (pH $6.9,800 \mathrm{ml}$ ) through a mixing flask containing $0.01 \mathrm{M} \mathrm{AcONH}_{4}$

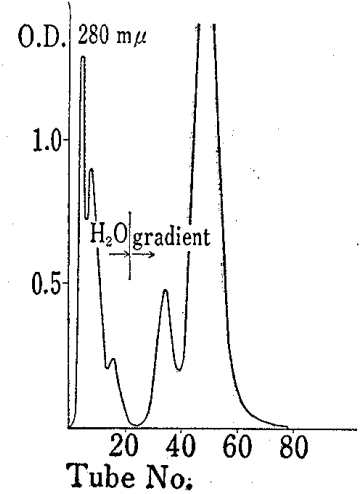

Fig. 4-a. Purification of Synthetic Camel $\beta_{2}-\mathrm{MSH}$ on CMCellulose

sample $100 \mathrm{mg}$

column $2.2 \times 4 \mathrm{~cm}$

Gradient buffer $0.1_{\mathrm{M}} \mathrm{AcONH}_{4} \mathrm{pH} 6.9$

fraction: $8 \mathrm{ml}$

mixing flask $0.01 \mathrm{M} \mathrm{AcONH}_{4}(200 \mathrm{ml})$ (pH 6.9, $200 \mathrm{ml})$. Individual fractions $(8 \mathrm{ml}$ each) were collected and absorbancy at $280 \mathrm{~m} \mu$ was determined. Fractions corresponding to the main peak (Fig. 4-a, Tube No 39-58) were combined and the solvent was removed by lyophilization. The residue was dissolved in $3 \% \mathrm{AcOH}(2 \mathrm{ml})$ and the solution was again applied to a column of Sephadex G-10 $(3.0 \times 140 \mathrm{~cm})$ for desalting. The product was isolated as stated above and finally lyophilized as a fluffy white powder; yield $38 \mathrm{mg}$ (purification step $38 \%$ ), $[\alpha]_{\mathrm{D}}^{20}-68.1^{\circ}(c=0.3$, $\left.\mathrm{H}_{2} \mathrm{O}\right), R f_{3} 0.33$. Disc electrophoretic mobility on $15 \%$ polyacrylamide gel $(0.5 \times 6.0 \mathrm{~cm}, 5 \mathrm{~mA} /$ tube $)$ at $\mathrm{pH} 2.3(0.37 \mathrm{~m}$ glycine-AcOH buffer $)$ was $3.6 \mathrm{~cm}$ after $130 \mathrm{~min}$ to the cathod. Paper (Toyo No. 51) electrophoretic mobility: $R f 0.48 \times$ Lys at $\mathrm{pH} 3.6$ pyridine acetate buffer (pyridine-AcOH- $\mathrm{H}_{2} \mathrm{O}=1: 10: 289,1100 \mathrm{~V}, 10 \mathrm{~mA}, 2 \mathrm{hr}$ ). (lit.5) $R f 0.48 \times$ Lys at $\mathrm{pH} 3.7$ ). Amino acid ratios in $3 \mathrm{~N}$ Tos-OH hydrolysate: Asp 2.00, Gly 3.13, Pro 3.12, Tyr 1.00, Lys 1.87, Met 0.88 , Glu 1.00, His 1.08, Phe 1.11, Arg 1.21, Trp 0.72, Ser 0.88 (average recovery $83 \%$ ). Amino acid ratios in AP-M digest: Asp 2.27, Gly 2.43, Pro 2.38, Tyr 1.00, Lys 1.90, Met 0.97, Glu 1.24, His 0.93 , Phe $1.10, \operatorname{Arg} 1.17$, Trp 0.81 , Ser 0.90 (average recovery of amino acids except Asp and Gly 86\%). Anal. Calcd. for $\mathrm{C}_{95} \mathrm{H}_{134} \mathrm{O}_{27} \mathrm{~N}_{26} \mathrm{~S}$. $3 \mathrm{CH}_{3} \mathrm{COOH}$ : (dried over $\mathrm{P}_{2} \mathrm{O}_{5}$ at $100^{\circ}$ for $3 \mathrm{hr}$ in vacuo): C, 53.10; $\mathrm{H}, 6.44 ; \mathrm{N}, 15.94$. Found: $\mathrm{C}, 53.74 ; \mathrm{H}, 5.83 ; \mathrm{N}, 15.91$.

Z(OMe)-Gln-His-OMe-Z Z $(\mathrm{OMe})-\mathrm{Gln}-\mathrm{ONP}(6.17 \mathrm{~g})$ was added to a solution of H-His-OMe (prepared from $3.15 \mathrm{~g}$ of the hydrochloride with $3.6 \mathrm{ml}$ of $\left.\mathrm{Et}_{3} \mathrm{~N}\right)$ in DMF $(50 \mathrm{ml})$ and the mixture was stirred at room temperature for $24 \mathrm{hr}$. The solvent was evaporated and the residue was treated with AcOEt to form a gelatinous mass, which was collected by filtration and then dissolved in $10 \%$ citric acid. The solution, after filtration, was basified with $\mathrm{NaHCO}_{3}$. The resulting gelatinous mass was washed batchwisely with $\mathrm{H}_{2} \mathrm{O}$ and precipitated twice from DMF with AcOEt; yield $4.45 \mathrm{~g}(74 \%)$, mp $176-179^{\circ},[\alpha]_{\mathrm{D}}^{20}+4.9^{\circ}(c=1.0, \mathrm{DMF})$. $R f_{1}$ 0.52. Anal. Calcd. for $\mathrm{C}_{21} \mathrm{H}_{27} \mathrm{O}_{7} \mathrm{~N}_{5}: \mathrm{C}, 54.65 ; \mathrm{H}, 5.90 ; \mathrm{N}, 15.18$. Found: $\mathrm{C}, 54.40 ; \mathrm{H}, 5.67 ; \mathrm{N}, 14.98$.

$\mathbf{Z}(\mathbf{O M e})-G \ln -\mathrm{His}-\mathrm{NHNH}_{2}-$ To a solution of $\mathrm{Z}(\mathrm{OMe})-\mathrm{Gln}-\mathrm{His}-\mathrm{OMe}(6.45 \mathrm{~g})$ in $\mathrm{DMF}-\mathrm{MeOH}(50 \mathrm{ml}-$ $10 \mathrm{ml}), 80 \%$ hydrazine hydrate $(7 \mathrm{ml})$ was added and the mixture, after standing overnight, was condensed in vacuo. The gelatinous mass formed by treatment with $\mathrm{MeOH}$, was precipitated from DMF with $\mathrm{MeOH}$; yield $4.61 \mathrm{~g}(70 \%), \operatorname{mp} 191-197^{\circ},[\alpha]_{\mathrm{D}}^{24}+11.8^{\circ}(c=0.7, \mathrm{DMSO}), R f_{1} 0.25$. Anal. Calcd. for $\mathrm{C}_{20} \mathrm{H}_{27} \mathrm{O}_{6} \mathrm{~N}_{7}$. $1 / 2 \mathrm{H}_{2} \mathrm{O}: \mathrm{C}, 51.05 ; \mathrm{H}, 6.00 ; \mathrm{N}, 20.84$. Found: C, $51.05 ; \mathrm{H}, 6.22 ; \mathrm{N}, 20.83$.

$\mathbf{Z}$ (OMe)-Gln-His-Phe-Arg(Tos)-Trp-Gly-OH_ZZ-Phe-Arg(Tos)-Trp-Gly-OH $\left.{ }^{7}\right) \quad(6.0 \mathrm{~g})$ dissolved in DMF $(60 \mathrm{ml})$ containing a few drops of $\mathrm{AcOH}$ was hydrogenated over a Pd catalyst for $8 \mathrm{hr}$. The catalyst was removed by filtration, the filtrate was condensed and the residue was treated with ether. The resulting powder (yield $4.39 \mathrm{~g}, 85 \%$ ) was dissolved in DMF $(40 \mathrm{ml})$, to which the azide (prepared from $3.36 \mathrm{~g}$ of $Z(\mathrm{OMe})-$ Gln-His-NHNH ${ }_{2}$ with $11.9 \mathrm{ml}$ of $2.03 \mathrm{~N} \mathrm{HCl-DMF}, 1.17 \mathrm{ml}$ of isoamylnitrite and $3.32 \mathrm{ml}$ of Et ${ }_{3} \mathrm{~N}$ ) in DMF $(40 \mathrm{ml})$ was combined. After stirring at $4^{\circ}$ for $48 \mathrm{hr}$, the solution was condensed in vacuo and the residue was treated with $3 \% \mathrm{AcOH}$. The resulting powder was washed with $3 \% \mathrm{AcOH}$ and $\mathrm{H}_{2} \mathrm{O}$ and then precipitated from DMF with MeOH; yield $5.49 \mathrm{~g}(76 \%), \mathrm{mp} 166-171^{\circ},[\alpha]_{\mathrm{D}}^{20}-25.1^{\circ}(c=0.9, \mathrm{DMF}), R f_{1} 0.48$. Anal. Calcd. for $\mathrm{C}_{55} \mathrm{H}_{65} \mathrm{O}_{13} \mathrm{~N}_{13} \mathrm{~S} \cdot 2 \mathrm{H}_{2} \mathrm{O}: \mathrm{C}, 55.78 ; \mathrm{H}, 5.87 ; \mathrm{N}, 15.38$. Found: $\mathrm{C}, 55.77 ; \mathrm{H}, 5.97 ; \mathrm{N}, 15.21$. 
Z(OMe)-Gln-His-Phe-Arg(Tos)-Trp-Gly-Ser -Pro-Pro-Lys (Z) - Asp (OBzl) _ Z (OMe)-Ser-Pro-Pro-Lys$\left.(Z)-A s p(O B z l)_{2}{ }^{7}\right)(2.23 \mathrm{~g})$ was treated with TFA $(4.5 \mathrm{ml})$ in the presence of anisole $(2.5 \mathrm{ml})$ in an ice-bath for 60 min and the excess TFA was removed by evaporation in vacuo. The residue was washed with petroleum ether, dried over $\mathrm{KOH}$ pellets in vacuo for $3 \mathrm{hr}$ and then dissolved in AcOEt, which under cooling with ice, was basified with $5 \% \mathrm{NaHCO}_{3}$. The organic phase was washed with $\mathrm{H}_{2} \mathrm{O}-\mathrm{NaCl}$, dried over $\mathrm{Na}_{2} \mathrm{SO}_{4}$ and then condensed at $30^{\circ}$. The residue was dissolved in DMF $(15 \mathrm{ml})$, to which HOBT $(0.3 \mathrm{~g}), Z(\mathrm{OMe})-\mathrm{Gln}-\mathrm{His}-$ Phe-Arg(Tos)-Trp-Gly-OH (1.89 g) and DCC $(0.37 \mathrm{~g})$ were added consecutively. The mixture was stirred at room temperature for $48 \mathrm{hr}$ and then filtered. The filtrate was condensed and the residue was treated with $\mathrm{H}_{2} \mathrm{O}$. The resulting powder was dissolved in a small amount of the solvent consisting of $\mathrm{CHCl}_{3}-\mathrm{MeOH}_{-}$ $\mathrm{H}_{2} \mathrm{O}-\mathrm{DMF}(60: 10: 1: 20)$ and the solution was applied to a column of silica gel $(2,8 \times 12 \mathrm{~cm})$, which was eluted with the same solvent. Fractions containing the substance of $R f_{1} 0.54$ were combined and the solvent was evaporated. Treatment of the residue with $\mathrm{H}_{2} \mathrm{O}$ afforded a fine powder, which was precipitated from DMF with ether; yield $1.41 \mathrm{~g}(32 \%), 130-132^{\circ},[\alpha]_{\mathrm{D}}^{20}-44.0^{\circ}(c=1.0, \mathrm{DMF}), R f_{1} 0.54$. Amino acid ratios in $6 \mathrm{~N} \mathrm{HCl} \mathrm{hydrolysate:} \mathrm{Glu} \mathrm{1.02,} \mathrm{His} 0.95$, Phe 0.99, Arg 1.01, Gly 1.00, Ser 0.89, Pro 2.17, Lys 0.98 , Asp 1.00 (average recovery $91 \%$ ). Amino acid ratios in $3 \mathrm{~N}$ Tos-OH hydrolysate: Glu 1.00, His 0.85 , Phe 0.81 , Trp 1.14, Gly 1.00, Ser 0.89, Pro 2.00, Lys 0.93, Asp 1.02 (average recovery $82 \%$ ). Anal. Calcd. for $\mathrm{C}_{100} \mathrm{H}_{119} \mathrm{O}_{23^{-}}$ $\mathrm{N}_{19} \mathrm{~S} \cdot \mathrm{H}_{2} \mathrm{O}: \mathrm{C}, 59.89 ; \mathrm{H}, 6.08 ; \mathrm{N}, 13.27$. Found: $\mathrm{C}, 59.85 ; \mathrm{H}, 6.10 ; \mathrm{N}, 13.51$.

Z(OMe)-Pro-Tyr-Lys(Z)-Met-Gln-His-Phe-Arg (Tos) - Trp - Gly-Ser - Pro-Pro-Lys (Z) - Asp (OBzl $)_{2}$-The above protected undecapeptide ester $(0.92 \mathrm{~g})$ was treated with TFA $(1.5 \mathrm{ml})$ in the presence of anisole $(1.0 \mathrm{ml})$ containing $2 \%$ ethanedithiol in an ice-bath for $60 \mathrm{~min}$ and dry ether was added. The resulting powder was collected by filtration, dried over $\mathrm{KOH}$ pellets in vacuo for $3 \mathrm{hr}$ and then dissolved in DMF ( $3 \mathrm{ml}$ ), to which $\mathrm{Et}_{3} \mathrm{~N}(0.13 \mathrm{ml})$ and the azide (prepared from $0.51 \mathrm{~g}$ of $\mathrm{Z}(\mathrm{OMe})-\mathrm{Pro}-\mathrm{Tyr}-\mathrm{Lys}(\mathrm{Z})-\mathrm{Met}-\mathrm{NHNH}_{2}, 0.44 \mathrm{ml}^{\mathrm{O}}$ of $2.98 \mathrm{~N} \mathrm{HCl}-\mathrm{DMF}, 0.09 \mathrm{ml}$ of isoamylnitrite and $0.28 \mathrm{ml}$ of $\left.\mathrm{Et}_{3} \mathrm{~N}\right)$ in DMF $(3 \mathrm{ml})$ were combined. The mixture was stirred at $4^{\circ}$ for $48 \mathrm{hr}$ and the solvent was evaporated. Treatment of the residue with $\mathrm{H}_{2} \mathrm{O}$ afforded a fine powder, which was washed batchwisely with $3 \%$ citric acid and $\mathrm{H}_{2} \mathrm{O}$ and then precipitated twice from THF with AcOEt; yield $1.02 \mathrm{~g}(84 \%), \mathrm{mp} 155-157^{\circ},[\alpha]_{\mathrm{D}}^{20}-44.4^{\circ}(c=1.0, \mathrm{DMF}), R f_{1} 0.54$. Amino acid ratios in $6 \mathrm{~N} \mathrm{HCl}$ hydrolysate: Pro 2.85, Tyr 1.00, Lys 1.88, Met 0.96, Glu 1.20, His 1.07, Phe 1.04, Arg 1.09, Gly 1.00, Ser 0.77, Asp 0.87 (average recovery 86\%). Amino acid ratios in 3N Tos-OH hydrolysate: Pro 3.03, Tyr 1.11, Lys 1.91, Met 0.86, Glu 1.18, His 1.00, Phe 0.97, Trp 1.09, Gly 1.00, Ser 0.83, Asp 0.94 (average recovery $82 \%$ ). Anal. Calcd. for $\mathrm{C}_{133} \mathrm{H}_{162} \mathrm{O}_{30} \mathrm{~N}_{24} \mathrm{~S}_{2} \cdot 4 \mathrm{H}_{2} \mathrm{O}: \mathrm{C}, 58.88 ; \mathrm{H}, 6.32 ; \mathrm{N}, 12.39$. Found: $\mathrm{C}, 58.76$; $\mathrm{H}, 6.10 ; \mathrm{N}, 12.58$.

Z(OMe)-Asp(OBzl)-Gly-Gly-Pro-Tyr-Lys(Z)-Met-Gln-His-Phe - Arg (Tos) - Trp - Gly - Ser - Pro - Pro - Lys (Z)$\operatorname{Asp}(\mathbf{O B z l})_{2}$ — The above protected pentadecapeptide ester $(0.51 \mathrm{~g})$ was treated with TFA $(1.0 \mathrm{ml})$ in the presence of anisole $(0.7 \mathrm{ml})$ containing $2 \%$ ethanedithiol in an ice-bath for 60 min and dry ether was added. The resulting powder was collected by filtration, dried over $\mathrm{KOH}$ pellets in vacuo for $3 \mathrm{hr}$ and then dissolved in DMF $(2 \mathrm{ml})$ containing $\mathrm{Et}_{3} \mathrm{~N}(0.05 \mathrm{ml})$. To this solution, the azide (prepared from $0.20 \mathrm{~g}$ of $\mathrm{Z}(\mathrm{OMe})-$ Asp(OBzl)-Gly-Gly-NHNH ${ }_{2}$ with $0.28 \mathrm{ml}$ of $2.98 \mathrm{~N} \mathrm{HCl-DMF}, 0.06 \mathrm{ml}$ of isoamylnitrite and $0.11 \mathrm{ml}$ of $E t_{3} \mathrm{~N}$ ) in DMF (2 ml) was combined and the mixture was stirred at $4^{\circ}$ for $48 \mathrm{hr}$, meanwhile the pH of the solution was examined in several times and maintained around at 7.5 with $\mathrm{Et}_{3} \mathrm{~N}$. A few drops of $\mathrm{AcOH}$ was added, the solvent was evaporated and the residue was treated with $3 \% \mathrm{AcOH}$. The resulting powder was washed batchwisely with $3 \% \mathrm{AcOH}$ and $\mathrm{H}_{2} \mathrm{O}$ and then precipitated twice from THF with AcOEt; yield $0.48 \mathrm{~g}(84 \%), \mathrm{mp} 157$ $161^{\circ},[\alpha]_{\mathrm{D}}^{20}-36.3^{\circ}(c=1.1, \mathrm{DMF}), R f_{1} 0.53$. Amino acid ratios in an acid hydrolysate: Asp 2.06, Gly 2.82, Pro 2.63, Tyr 0.96, Lys 1.84, Met 1.00, Glu 0.97, His 1.05, Phe 1.09, Arg 1.10, Ser 0.76 (average recovery $86 \%$ ). Amino acid ratios in $3 \mathrm{~N}$ Tos-OH hydrolysate: Asp 2.16, Gly 3.03, Pro 2.82, Tyr 1.09, Lys 1.88, Met 0.78, Glu 1.04, His 1.00, Phe 1.07, Trp 0.83, Ser 0.89 (average recovery $84 \%$ ). Anal. Calcd. for $\mathrm{C}_{148} \mathrm{H}_{179} \mathrm{O}_{35} \mathrm{~N}_{27} \mathrm{~S}_{2} \cdot 5 \mathrm{H}_{2} \mathrm{O}: \mathrm{C}, 58.27 ; \mathrm{H}, 6.25 ; \mathrm{N}, 12.40$. Found: $\mathrm{C}, 58.11 ; \mathrm{H}, 6.23 ; \mathrm{N}, 12.51$.

H - Asp-Gly - Gly-Pro-Tyr-Lys-Met-Gin-His-Phe-Arg-Trp-Gly-SerPro-Pro-Lys-Asp-OH, Camel $\boldsymbol{\beta}_{\mathbf{1}}$-MSH (I)—The above protected octadecapeptide ester $(296 \mathrm{mg}$ ) was treated with HF (approximately $5 \mathrm{ml})$ in the presence of anisole $(0.5 \mathrm{ml})$ skatole $(65 \mathrm{mg})$ and dithiothreitol $(24 \mathrm{mg})$ in an ice-bath for $60 \mathrm{~min}$. The excess HF was evaporated at $0^{\circ}$ and dry ether was added. The resulting powder was dissolved in $\mathrm{H}_{2} \mathrm{O}(20 \mathrm{ml})$, which was treated with Amberlite CG-4B (type II, acetate form, $c a .3 \mathrm{~g}$ ) for $30 \mathrm{~min}$ and then filtered. The filtrate was lyophilized, the residue $(234 \mathrm{mg})$ was dissolved in $3 \%$ $\mathrm{AcOH}(5 \mathrm{ml})$ and the solution was applied to a column of Sephadex $\mathrm{G}-10(3.0 \times 140 \mathrm{~cm})$, which was eluted with $3 \% \mathrm{AcOH}$. Individual fractions $(3 \mathrm{ml}$ each) were collected and absorbancy at $280 \mathrm{~m} \mu$ was determined. Fractions corresponding to the front main peak (tube

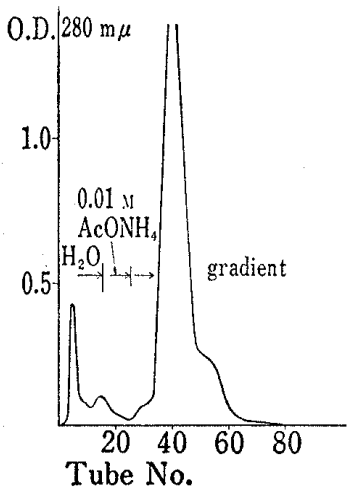

Fig. 4-b. Purification of Synthetic Camel $\beta_{1}-\mathrm{MSH}$ on CMCellulose

sample $100 \mathrm{mg}$

column $2.2 \times 4 \mathrm{~cm}$

Gradient buffer $0.1 \mathrm{McONH} \mathrm{AcH}_{4} \mathrm{pH}$

fraction: $7.5 \mathrm{ml}$

mixing flask $0.01_{\mathrm{M} \mathrm{AcONH}}(150 \mathrm{ml})$ 
No $71-130)$ were combined and the solvent was removed by lyophilization to give a fluffy powder; yield $205 \mathrm{mg}$ (deblocking step $87 \%$ ). For the next purification, the product $\left(100 \mathrm{mg}\right.$ ) was dissolved in $\mathrm{H}_{2} \mathrm{O}$ $(5 \mathrm{ml})$ and the solution was applied to a column of CM-cellulose $(2.2 \times 4.0 \mathrm{~cm})$, which was first eluted with $\mathrm{H}_{2} \mathrm{O}(100 \mathrm{ml})$ and then with $\mathrm{pH} 6.9,0.01 \mathrm{M} \mathrm{AcONH}{ }_{4}(75 \mathrm{ml})$. Gradient elution was next established with $0.1 \mathrm{M} \mathrm{AcONH}_{4}(\mathrm{pH} 6.9,800 \mathrm{ml})$ through a mixing flask $(150 \mathrm{ml})$ containing $0.01 \mathrm{M} \mathrm{AcONH} \cdot \mathrm{Andividual}_{4}$ fractions $(7.5 \mathrm{ml}$ each) were collected and absorbancy at $280 \mathrm{~m} \mu$ was determined. Fractions corresponding. to the main peak (Fig. 4-b, tube No 37-49) were combined and the solvent was removed by lyophilization. The residue was dissolved in a small amount of $3 \% \mathrm{AcOH}$ and the solution was applied to a column Sephadex G-10 $(3.0 \times 140 \mathrm{~cm})$, which was eluted with $3 \% \mathrm{AcOH}$ for desalting. The product was isolated as stated above and finally lyophilized as a fluffy white powder; yield $31 \mathrm{mg}$ (purification step $31 \%$ ). $[\alpha]_{\mathrm{D}}^{16}-62.9^{\circ}$ $\left(c=0.2, \mathrm{H}_{2} \mathrm{O}\right), R f_{3} .0 .58$. Disc electrophoretic mobility on $15 \%$ polyacrylamide gel $(0.5 \times 6.0 \mathrm{~cm}, 5 \mathrm{~mA} / \mathrm{tube})$ at $\mathrm{pH} .2 .3(0.37 \mathrm{M}$ glycine-AcOH buffer $)$ was $3.5 \mathrm{~cm}$ after $130 \mathrm{~min}$ to the cathod. Paper electrophoretic

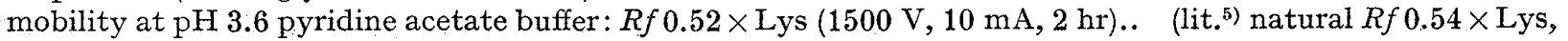
synthetic $0.52 \times$ Lys at $\mathrm{pH}$ 3.7). Amino acid ratios in a $3 \mathrm{~N}$ Tos-OH hydrolysate: Asp 2.21, Gly 3.35, Pro 3.33 , Tyr 1.00 , Lys 1.95 , Met 0.87 , Glu 1.14 , His 0.80 , Phe 0.99 , Arg 0.88 , Trp 0.86, Ser 1.00 (average recovery 84\%). Amino acid ratios in an AP-M digest: Asp 1.82, Gly 2.79, Pro 3.36, Tyr 1.07, Lys 2.30, Met 0.82, Gln 1.06, His 0.92, Phe 1.0.0, Arg 1.00, Trp 0.92, Ser 1.07 (average recovery of amino acids except Asp and Gly $88 \%$ ). Anal. Calcd, for $\mathrm{C}_{95} \mathrm{H}_{135} \mathrm{O}_{26} \mathrm{~N}_{27} \mathrm{~S} \cdot 3 \mathrm{CH}_{3} \mathrm{COOH} \cdot 3 \mathrm{H}_{2} \mathrm{O}: \mathrm{C}, 51.89 ; \mathrm{H}, 6.60 ; \mathrm{N}, 16.18$. Found: C, $52.12 ; \mathrm{H}, 6.10 ; \mathrm{N}, 15.92$. 